\title{
Tax preferences, dividends and lobbying for maximum value
}

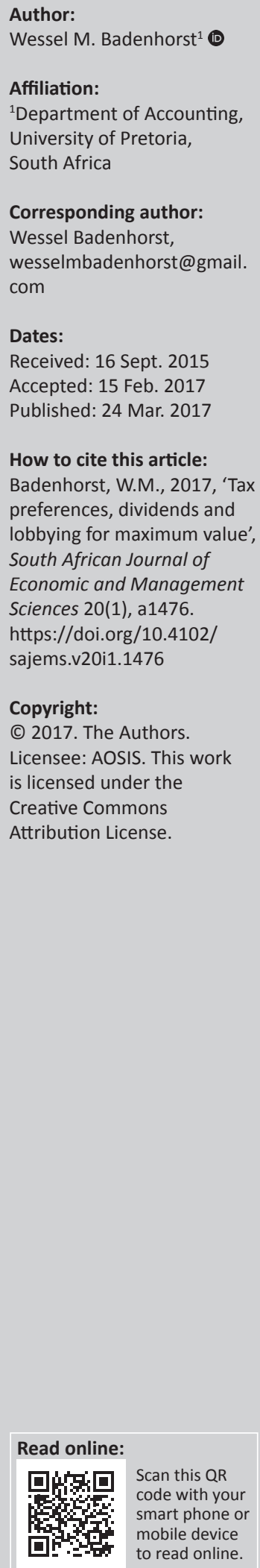

Background: The value of equity investments depends to some extent on the tax consequences for investors. When groups of investors have different tax preferences, this can lead to conflicting pressures on firms to either retain earnings or pay dividends. The findings of this study will be of interest to researchers of taxation and corporate governance alike, as they highlight the role that corporate shareholders play in the decisions of the firm. Investors and regulators will also be interested in the findings as they reveal more about the interaction between shareholders with conflicting interests. Lastly, changes in behaviour as a result of changes in tax legislation are of interest to those with fiscal responsibility.

Setting: A 2012 dividend tax change in South Africa, which simultaneously altered the tax preferences of individual and corporate investors, provides a unique opportunity to investigate firms' reaction to their investors' tax preferences.

Aim: This article seeks to determine whether firms respond to changes in their investors' tax preferences in their decisions to either retain earnings or pay dividends.

Method: The article investigates the responses of firms to the 2012 dividend tax change using multivariate regressions.

Results: Findings show that firms consider changes in the tax preferences of their investors in setting dividend policies. In addition, it appears that corporates have greater success in lobbying for beneficial dividend changes than individuals.

Conclusion: Changes in investors' tax preferences impact on firms' dividend policy decisions. These decisions ultimately affect the value of the firm to its investors.

\section{Introduction}

A general finance principle holds that the value of an investment is the present value of its future post-tax cash flows (Ilmanen 2011:66; Shrieves \& Wachowicz 2001). It follows, firstly, that maximising future cash flows maximises the value of an investment. A second implication is that minimising future tax outflows can improve value outcomes. When the tax consequences depend on the nature of the cash flow (e.g. income or capital), investors develop a preference for the lower tax alternative. However, groups of investors (e.g. individuals vs. corporates) frequently have different tax preferences, as tax consequences also depend on the identity of the investor. When investors with differing tax preferences invest in the equity of the same firm, this can lead to conflicting pressures on management to either retain earnings or distribute profits to investors. This article, therefore, investigates the response of firms when their investors have conflicting tax preferences.

The setting for this article is a recent change in South African dividend tax on 1 April 2012, which replaced a $10 \%$ tax on firms with a $15 \%$ tax on shareholders. Importantly, this tax change altered the tax preferences of two groups of investors, namely, individuals and corporates, simultaneously. Toerien and Marcus (2014) provide descriptive evidence that, subsequent to the tax change in South Africa, corporate investors prefer dividends from a tax perspective. Similarly, they find that individual investors prefer capital gains when tax is the only consideration. The South African situation, therefore, allows for an investigation of the impact of changes in tax preferences on dividends and also of the relative influence of corporate and individual shareholders.

This is important, as prior research provides limited insights when tax preferences of shareholders alter in a conflicting manner. Bond, Devereux and Klemm (2005) found that tax reforms affecting institutional investors in the United Kingdom altered the form of dividends, but not their level. 
Other research shows that Norwegian and Finnish firms increased dividends prior to tax increases for individuals (Alstadsæter \& Fjærli 2009; Kari, Karikallio \& Pirttilä 2008). However, the tax changes in these countries affected only one investor group, and it is not possible to determine whether conflicting tax preferences of another investor group limited dividend increases.

Using a multivariate regression approach, this study considers the impact of corporate shareholding on growth in dividends prior and subsequent to the 2012 tax change for a sample of South African firms. This approach effectively tests the significance of changes in dividend growth before and after the tax change (related to a difference in difference approach). In addition, findings are cross-checked against an earlier tax change during 2007 (the control sample). Although this tax change aligned the tax preferences of individual and corporate investors, the South African government simultaneously announced its future intentions in respect of dividend tax changes.

Findings show a significantly positive (negative) association between corporate shareholding and growth in dividends after (before) the 2012 tax change. In other words, after (before) this tax change, firms with higher corporate shareholding grew their dividends significantly faster (slower) than other firms. These findings imply that corporate shareholders had sufficient influence to align dividend policies of their investees with their tax preferences. This could be because of the size of their holdings or merely reflect that corporate investors tend to be better at organised lobbying than individuals. By contrast, findings for the control sample show that corporate shareholding had a limited impact on growth in dividends as a result of the 2007 tax change. In summary, this study, therefore, concludes that tax preferences of investors affect dividends. In addition, when tax preferences conflict, corporates appear to have greater influence over their investees than individuals.

This study contributes to the existing literature by revealing that investors place pressure on firms to minimise their own tax burden and that firms adjust their dividend policies in response. In addition, it shows that, in the face of conflicting tax preferences, corporates appear to have greater influence than individuals.

The findings of this study will be of interest to researchers of taxation and corporate governance alike, as they highlight the role that corporate shareholders play in the decisions of the firm. Investors and regulators will also be interested in the findings, as they reveal more about the interaction between shareholders with conflicting interests. Lastly, changes in behaviour as a result of changes in tax legislation are of interest to those with fiscal responsibility.

The remainder of this article is organised as follows: the next section reviews the prior literature, followed by a discussion of dividend tax in South Africa. Then, the research methodology is set out, followed by the sample selection, descriptive statistics and univariate investigations. The detailed multivariate regression results are discussed in a separate section, followed by the results of additional analyses and robustness tests. The final section summarises and concludes the article.

\section{Literature review}

Investors are concerned with maximising the value of each of their investments, which is affected by the tax consequences associated with it. As a result, investors have an incentive to pressure firms to alter their decisions to improve tax outcomes. Firms have an incentive to comply, as greater investor demand increases their market value, which in turn reduces the risk of takeovers and increases executive compensation.

Some research findings support such a conclusion. Ayers, Cloyd and Robinson (2002) found that a dividend tax increase in the United States during 1993 affected stock returns, depending on the dividend policy of a firm and the tax status of marginal investors. Similarly, a number of researchers found that firms in the United States increased their dividend payments after a tax cut during 2003 (Blouin, Raedy \& Shackelford 2011; Chetty \& Saez 2005). By contrast, Amromin, Harrison and Sharpe (2008) contended that the 2003 dividend tax cut in the United States affected a minority of investors (i.e. individual investors). They found no aggregate impact on the stock market and concluded that the tax cut affected individual investors, but not the dividend decisions of firms. This view is supported by Edgerton (2013) who argued that several contemporaneous events led to the increase in dividends during 2003.

Research on tax changes in Norway and Finland finds that firms in these countries increased dividends prior to dividend tax increases on individuals (Alstadsæter \& Fjærli 2009; Kari, Karikallio \& Pirttilä 2008). In respect of institutional shareholders, Bond et al. (2005) found that tax reforms for pension funds in the United Kingdom changed the form of dividends, but not the level thereof. However, the tax changes in these countries affected only one investor group, and it is not possible to determine whether conflicting tax preferences of another investor group limited dividend increases.

In summary, prior researchers find that tax preferences of investors affect their own investment decisions. However, the impact on the dividend decisions of firms is less clear. This problem is exacerbated by the fact that most of the tax changes investigated by prior research affected only individuals. Although prior research shows that corporate shareholders have a significant impact on dividend policy (Bond et al. 2005; Moser 2007; Short, Zhang \& Keasey 2002), the question is whether changes in their tax preferences affect growth in dividends. This question is especially relevant when changes in tax preference of corporates correspond with simultaneous, but opposite, changes in the tax preferences of other investors. In this context, recent changes in South African dividend tax legislation provide a unique opportunity for further investigation. 


\section{Dividend taxation in South Africa}

In most countries, dividends are taxed in the hands of the recipient. However, from 1993 to 2012, firms in South Africa were taxed on dividends they declared under a system known as 'Secondary Tax on Companies' (STC). During this time, dividends were collected as tax free income by recipients. In the main, all dividend declarations were subjected to STC, regardless of the identity or nature of the recipient, although subsidiaries had a choice to exempt dividends paid to their parents. However, if the recipient was also subject to STC, it reduced its own STC liability based on dividends received (if the dividends received had been subject to STC).

The rate of STC initially fluctuated but remained stable at 12.5\% from 14 March 1996 to 30 September 2007. During 2007, the South African government announced its intention of aligning South African dividend tax practices with international norms. This entailed that STC (a tax on the dividend payer) would be replaced with dividend tax (a tax on the dividend recipient). As an initial step in this direction, the STC rate was decreased to $10.0 \%$ for dividends declared on or after 1 October 2007.

An important aspect of dividend tax is its interaction with capital gains tax. Simply put, the South African capital gains tax is levied on the difference between the proceeds received upon the sale of an investment and the price initially paid for it (base cost). As the tax regimes for dividends and capital gains differ, this may affect investors' tax preferences for receiving dividends or retaining income in the firm. As Toerien and Marcus (2014) illustrate, capital gains tax would have been lower than STC for most South African equity investors prior to 1 October 2007. As a result, with the exception of individuals, South African investors preferred to retain income (as opposed to receiving dividends) if tax considerations were the only relevant factor. With the change of the STC rate in 2007, Toerien and Marcus (2014) calculated that all investors, including individuals, subsequently preferred to retain income from a tax perspective.

However, on 1 April 2012, STC was finally replaced with dividend tax in respect of dividends declared on or after that date. This change altered the tax preferences of investors yet again. Dividend tax is levied at a rate of $15.0 \%$ and is a tax on the dividend recipient. Importantly, some recipients are exempt from the tax, notably South African firms (i.e. corporate investors) who receive the income tax free (they withhold dividend tax from their own dividend payments). Toerien and Marcus (2014) calculated that dividend tax was lower for corporate investors than capital gains taxes after this tax change, while the opposite was true for individuals. Although Toerien and Marcus (2014) speculate that this would lead corporate investors to prefer dividends over retained income, they do not investigate this empirically. In another study related to this tax change, Coetzee and De Wet (2014) used an event study approach and found that the share prices of South African firms who increased their dividend pay-out ratios in response to the tax change reacted abnormally positively to dividend announcements. However, their paper does not shed light on the role that conflicting tax preferences of shareholders played.

From the above discussion, it is clear that the South African situation allows for unique empirical investigations. Prior research on dividend tax changes has been criticised by some, as these tax changes only affected individuals who make up a minority of shareholders (Amromin et al. 2008). By contrast, the South African tax change caused a tax preference for higher dividend payments amongst corporates and simultaneously introduced a tax preference for retained earnings amongst individuals. As all taxpayers were affected by the tax changes, a broader investigation than that of prior research is possible.

\section{Research methodology}

This article uses a multivariate regression approach to investigate the impact of changing tax preferences on dividends. To reduce the effect of contemporaneous changes, investigations focus on the impact of corporate shareholding on growth in dividends prior and subsequent to the tax change in 2012. This approach effectively tests the significance of changes in dividend growth (related to a difference in difference approach). It firstly eliminates omitted correlated variables that remain constant over time and secondly removes omitted correlated variables that change by a constant factor over time. In addition, findings are crosschecked against an earlier tax change during 2007 (the control sample).

The following model is regressed for firm $i$, period $t$ in the year immediately before and after each tax change:

$$
\begin{aligned}
\mathrm{DPS}_{i, t}= & \mathrm{ROA}_{i, t}+\mathrm{LOSS}_{i, t}+\mathrm{RE}_{i, t}+\mathrm{CF}_{i, t}+\mathrm{CASH}_{i, t}+\mathrm{DE}_{i, t}+\mathrm{GTH}_{i, t} \\
& +\mathrm{PD}_{i, t}+\operatorname{RESTR}_{i, t}+\mathrm{SIZE}_{i, t}+\mathrm{EMP}_{i, t}+\mathrm{CORP}_{i, t}+\varepsilon
\end{aligned}
$$

where DPS is the growth (change) in total dividends per share declared from the previous period (excluding special dividends). ${ }^{1}$ ROA is the change in return on total assets, calculated as earnings before interest and tax divided by average total assets (DeAngelo, DeAngelo \& Stulz 2006). It controls for profitability, as more profitable firms pay higher dividends. LOSS, an indicator set to one if a firm reports a basic loss per share and zero otherwise, is included for similar reasons. $\mathrm{RE}$ is the change in retained earnings as a percentage of common equity. Prior research finds that firms with a greater percentage of retained earnings to equity are more mature and tend to pay higher dividends (Brockman \& Unlu 2011; DeAngelo et al. 2006).

Cash on hand is an important limiting factor for dividend payments. Following prior research (Al-Ajmi \& Hussain 2011; Brockman \& Unlu 2011; DeAngelo et al. 2006), the model

1.Note that the Worldscope data item on Datastream is adjusted for events such as stock splits and share consolidations. This ensures the comparability of the data across sample years. 
controls for changes in cash and cash equivalents per share (CASH). For similar reasons, the model includes an indicator variable $(\mathrm{CF})$ set to one if a firm reports negative cash flow generated by operations and zero otherwise. Leverage, including debt and preference share capital, limits dividends to ordinary shareholders because of contractual restraints. $\mathrm{DE}$ is the change in the ratio of total assets to total common equity, calculated using book values (DeAngelo et al. 2006).

Firms with greater growth opportunities tend to reinvest earnings, rather than distribute it. GTH represents the change in the 3-year annual compound growth rate in sales between period $t$ and period $t-1$ (DeAngelo et al. 2006). Dividends tend to be persistent (Goncharov \& van Triest 2011; Moser 2007) and PD controls for the change in dividend per share of the previous year. A number of studies found that shares held by employees affect the likelihood that dividends will be paid (Brown, Liang \& Weisbenner 2007; Minnick \& Rosenthal 2014). Consequently, the model controls for the percentage of common shares held by employees (EMP). ${ }^{2}$

The variable of interest is CORP, which is defined as the percentage of common shares held by corporate investors (i.e. the shares held by one company in another). If corporate shareholders have greater (less) influence than individual investors on firm's dividend policies, CORP will be significant and positive (negative) after the 2012 tax change. By contrast, insignificance for CORP would indicate that firms ignore the tax preferences of their investors in determining dividend policies or that they treat all their investors alike.

To compensate for the impact of outliers, all variables, other than indicator variables, are winsorised at the $1 \%$ and $99 \%$ levels.

\section{Sample selection}

The initial sample to assess the impact of the 2012 tax change consists of firms with a primary listing on the Johannesburg Stock Exchange (JSE) in South Africa on 31 March 2012 (the day before the tax change). This sample is reduced to include only those firms that were still listed on 31 March 2013 and for which all data items are available. The control sample is selected in a similar manner, using the firms with a primary listing on the JSE on 30 September 2007 (the day before the tax change). Once again the sample is reduced to include only those firms that were still listed on 30 September 2008 and for which all data items are available.

In both instances, only firms that paid a dividend in the year before the tax change are included in the final sample. Real estate investment trusts are eliminated from the sample, as these firms are not subject to dividend tax. The final sample numbers and industry composition are detailed in Table 1. Although sample numbers appear small, they represent

2. Ownership structures tend to be relatively stable over shorter periods of time which the descriptive statistics of this paper confirm. For this reason, the ownership percentages in this paper are not specified as changes therein.
TABLE 1: Sample composition.

\begin{tabular}{|c|c|c|c|c|}
\hline \multirow[t]{2}{*}{ Industry } & \multicolumn{2}{|c|}{ 2007-2008 sample } & \multicolumn{2}{|c|}{ 2012-2013 sample } \\
\hline & Number & $\%$ & Number & $\%$ \\
\hline Auto parts & 1 & 1 & 1 & 1 \\
\hline Business services & 2 & 2 & 3 & 2 \\
\hline Cement & 1 & 1 & 2 & 1 \\
\hline Chemical and allied products & 9 & 7 & 8 & 6 \\
\hline Clothing manufacturers & 1 & 1 & - & - \\
\hline Computer equipment & 1 & 1 & 2 & 1 \\
\hline Computer related services & 8 & 7 & 8 & 6 \\
\hline Construction & 3 & 2 & 5 & 3 \\
\hline Electronic and electrical equipment & 5 & 4 & 6 & 4 \\
\hline Financial services & 17 & 14 & 21 & 14 \\
\hline Food producers & 3 & 2 & 4 & 3 \\
\hline Food products & 8 & 7 & 10 & 7 \\
\hline Health services & 2 & 2 & 3 & 2 \\
\hline Hotels and gambling & 3 & 2 & 6 & 4 \\
\hline Industrial machinery and equipment & 2 & 2 & 2 & 1 \\
\hline Iron and steel products & 2 & 2 & 2 & 1 \\
\hline Media & 1 & 1 & 1 & 1 \\
\hline Mining & 10 & 8 & 12 & 8 \\
\hline Other services & 4 & 3 & 5 & 3 \\
\hline Paper, packaging and publishers & 5 & 4 & 3 & 2 \\
\hline Restaurants and pubs & 2 & 2 & 2 & 1 \\
\hline Retailers & 16 & 13 & 18 & 12 \\
\hline Telecommunications & 2 & 2 & 3 & 2 \\
\hline Transport & 7 & 6 & 8 & 6 \\
\hline Wholesalers & 5 & 4 & 10 & 7 \\
\hline Wood products & 1 & 1 & - & - \\
\hline Total & 121 & 100 & 145 & 100 \\
\hline
\end{tabular}

approximately $67 \%$ (58\%) of the available firms in the initial sample subject to dividend tax in 2007 (2012). No industry appears to dominate the sample, although retailers and financial services firms each comprise a little over $10 \%$ of the sample. All data items required for the purposes of this study are collected from Datastream. In isolated cases, missing values on the database are hand-collected from publically available financial statements.

\section{Descriptive statistics and univariate investigations}

The descriptive statistics contained in Table 2 show that the mean growth in dividend per share increased subsequent to the 2012 tax change from $11.8 \%$ in the previous year to $16.8 \%$. However, the median growth declined during the same period from $8 \%$ to $5 \%$. This implies that the observed increase in growth rates of dividends was not uniform and therefore that growth in dividends is influenced by a combination of different factors. The descriptive statistics also show that both the mean and the median growth in dividend per share decreased in the control sample subsequent to the 2007 tax change. This is in line with a change in tax preference for retaining earnings by all investors (Toerien \& Marcus 2014). However, without controlling for other factors, this offers limited insights because of the global financial crisis at the time.

The descriptive statistics in Table 2 also confirm that ownership structures tend to be relatively stable over 
TABLE 2: Descriptive statistics.

\begin{tabular}{|c|c|c|c|c|c|}
\hline Panel & Variable & $2007 \dagger$ & $2008 \dagger$ & 2012末 & 2013: \\
\hline \multirow[t]{13}{*}{ A: Mean } & DPS & 0.182 & 0.040 & 0.118 & 0.168 \\
\hline & ROA & -0.002 & -0.017 & -0.007 & -0.023 \\
\hline & LOSS & 0.017 & 0.050 & 0.014 & 0.124 \\
\hline & RE & 0.023 & 0.202 & 0.019 & 0.048 \\
\hline & $\mathrm{CF}$ & 0.099 & 0.050 & 0.097 & 0.103 \\
\hline & CASH & 0.124 & 0.340 & 0.249 & 0.889 \\
\hline & $\mathrm{DE}$ & -0.008 & 0.413 & 0.286 & -0.099 \\
\hline & GTH & 0.059 & -0.069 & 0.372 & -0.005 \\
\hline & PD & 0.505 & 0.182 & 0.350 & 0.118 \\
\hline & RESTR & 0.099 & 0.107 & 0.124 & 0.170 \\
\hline & SIZE & 0.312 & -0.265 & 0.174 & 0.170 \\
\hline & EMP & 0.034 & 0.033 & 0.085 & 0.081 \\
\hline & CORP & 0.177 & 0.182 & 0.162 & 0.163 \\
\hline \multirow[t]{13}{*}{ B: Median } & DPS & 0.120 & 0.052 & 0.080 & 0.050 \\
\hline & ROA & 0.001 & -0.007 & -0.001 & -0.011 \\
\hline & LOSS & 0.000 & 0.000 & 0.000 & 0.000 \\
\hline & $\mathrm{RE}$ & 0.016 & 0.018 & 0.006 & 0.001 \\
\hline & $\mathrm{CF}$ & 0.000 & 0.000 & 0.000 & 0.000 \\
\hline & CASH & 0.077 & 0.093 & 0.022 & 0.046 \\
\hline & $\mathrm{DE}$ & -0.008 & 0.059 & -0.004 & 0.037 \\
\hline & GTH & 0.014 & 0.005 & 0.033 & 0.003 \\
\hline & PD & 0.090 & 0.120 & 0.065 & 0.080 \\
\hline & RESTR & 0.000 & 0.000 & 0.000 & 0.000 \\
\hline & SIZE & 0.296 & -0.267 & 0.181 & 0.165 \\
\hline & EMP & 0.000 & 0.000 & 0.000 & 0.000 \\
\hline & CORP & 0.100 & 0.100 & 0.070 & 0.070 \\
\hline \multirow[t]{13}{*}{ C: Standard deviation } & DPS & 0.985 & 1.801 & 1.326 & 0.966 \\
\hline & ROA & 0.157 & 0.121 & 0.063 & 0.069 \\
\hline & LOSS & 0.128 & 0.218 & 0.117 & 0.331 \\
\hline & RE & 0.227 & 2.270 & 0.112 & 0.245 \\
\hline & CF & 0.300 & 0.218 & 0.296 & 0.306 \\
\hline & CASH & 6.718 & 13.179 & 3.251 & 8.012 \\
\hline & $\mathrm{DE}$ & 1.524 & 6.681 & 2.911 & 3.365 \\
\hline & GTH & 0.302 & 0.659 & 0.227 & 0.298 \\
\hline & PD & 3.709 & 0.985 & 1.063 & 1.326 \\
\hline & RESTR & 0.300 & 0.311 & 0.331 & 0.373 \\
\hline & SIZE & 0.324 & 0.315 & 0.243 & 0.334 \\
\hline & EMP & 0.099 & 0.096 & 0.164 & 0.158 \\
\hline & CORP & 0.214 & 0.221 & 0.210 & 0.220 \\
\hline
\end{tabular}

DPS, change in total dividend per share declared, excluding special dividends; ROA, change in return on total assets for the period, calculated as the change in earnings before interest and tax divided by average total assets in the current and prior period; LOSS, indicator variable set to one if a firm reports a basic loss per share and zero otherwise; RE, change in retained earnings as a divided by average total assets in the current and prior period; LOSS, indicator variable set to one if a firm reports a basic loss per share and zero otherwise; RE, change in retained earnings as percentage of common equity; $\mathrm{CF}$, indicator variable set to one if a firm reports negative cash generated by operations and zero otherwise; $\mathrm{CASH}$, change in cash and cash equivalents per share; $\mathrm{DE}$, change in leverage, calculated as the book value of total assets to the book value of common equity in each period; GTH, change in 3-year annual compound growth rate in sales between the current and prior periods; PD, change in prior year dividend per share; RESTR, indicator variable set to one if the firm has discontinued operations in the current year and zero otherwise; SIZE, change in size, calculated as the natural log of the market value of the firm in each period; EMP, the percentage of outstanding common shares held by employees; CORP, the percentage of outstanding common shares held by corporate investors.

$\dagger, N=121 ; \pm, N=145$

shorter periods. The difference in mean shareholding by employees (EMP) and corporates (CORP) is marginal between sequential years, while the median shareholdings are unchanged. For the main sample, mean (median) corporate shareholding is 16.2\% (7.0\%) in 2012 and 16.3\% (7.0\%) in 2013. By implication, most firms in the sample have corporate shareholders, although the extent of their holding differs. Untabulated statistics show that the maximum corporate shareholding is close to $90 \%$ in each of the sample years.

To investigate the impact of corporate shareholding on dividend per share, the sample is stratified into firms with corporate shareholding above and below the median in each of the sample years. Panel A of Table 3 shows that the mean dividend per share (level) does not differ significantly between the subsamples in any of the sample years. However, subsequent to the 2012 tax change, corporate investors prefer dividends to capital gains. The growth in dividends (change) for firms with corporate shareholdings above the median $(30.9 \%)$ is significantly higher than the rest of the firms $(2.8 \%)$ in 2013 at the $10 \%$ level of significance $(p=0.088)$. Interestingly, 2013 is the only sample year in which the growth in dividends is higher for firms with high corporate shareholding. These comparisons, therefore, suggest that corporate investors successfully lobbied for higher dividends in line with their new tax preference after the 2012 tax change.

The Pearson correlations in Panel B of Table 3 further support this conclusion. Higher corporate shareholding is associated with significantly higher growth in dividends subsequent to 


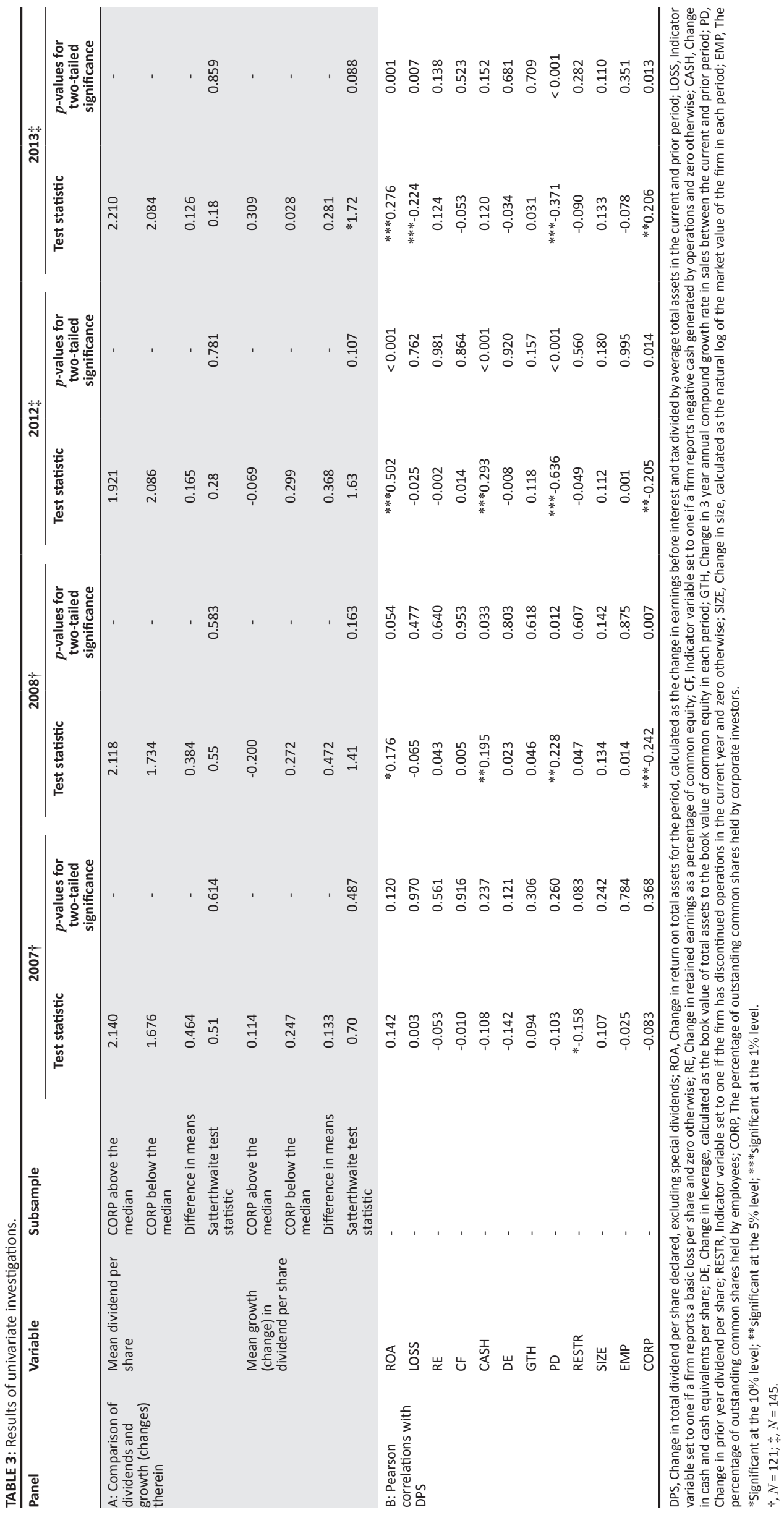


the 2012 tax change at the $5 \%$ level $(p=0.013)$. In addition, these results suggest that corporate investors were holding back growth in dividends in anticipation of the tax change during 2012. For this year, higher corporate shareholding is associated with significantly lower growth in dividends at the $5 \%$ level $(p=0.014)$.

By contrast, prior to the announcement of impending changes in tax policy during 2007, the degree of corporate shareholding had an insignificant impact on growth in dividends ( $p=$ 0.368). In addition, correlations for 2008 suggest that corporate investors were holding back growth in dividends in anticipation of the tax change for a considerable period of time. Higher corporate shareholding is associated with significantly lower growth in dividends during 2008 at the $1 \%$ level $(p=0.007)$.

The above findings, therefore, offer some preliminary evidence that changes in the tax preferences of corporate investors because of the 2012 tax change affected growth in dividends. However, this study relies on the results of multivariate investigations for its conclusions. These results are detailed in the sections that follow.

\section{Detailed regression findings}

Table 4 details the main results for this study from ordinary least squares regression. These results reflect that more profitable firms consistently have higher growth in dividends, with ROA positive and significant at the $10 \%$ level or better in every sample year. None of the other control variables affect growth in dividends with the same level of consistency, although growth in cash (CASH), changes in growth rates
(GTH) and restructuring (RESTR) all affected growth rates significantly in one or more sample years.

More importantly, the results in Table 4 show that higher corporate shareholding subsequent to the 2012 tax change resulted in significantly higher growth in dividends at the 5\% level $(p=0.040)$. These facts imply two important conclusions. Firstly, firms consider the tax preferences of their investors in determining dividend policies. Secondly, corporate investors appear to be more successful at applying pressure on their investees than individual investors in the face of conflicting tax preferences. Interestingly, findings also imply that corporate investors lobbied successfully for slower growth in dividends prior to the tax change, as CORP is negative and significant at the $5 \%$ level $(p=0.040)$ in 2012. In addition, a Chow-test (Chow 1960) shows that the factors affecting dividend growth during 2013 differ significantly from those in 2012 at the $1 \%$ level $(p=0.004)$.

In contrast, findings from the control sample show that corporate shareholding had an insignificant impact on dividend growth prior to the announcement of impending tax changes during 2007 ( $p=0.476$ ). The results also suggest that corporate investors successfully lobbied for slower dividend increases by their investees for a considerable period of time prior to the tax change. CORP is negative and significant at the $10 \%$ level ( $p=0.099$ ) for the 2008 sample. In addition, a Chow-test (Chow $1960)$ shows that the factors affecting dividend growth during 2008 differ significantly from those in 2007 at the $1 \%$ level $(p<0.001)$. Results for the control sample, therefore, suggest that corporate shareholding does not have an impact on growth in dividends independently of known or anticipated changes in tax legislation.

TABLE 4: Main regression results.

\begin{tabular}{|c|c|c|c|c|c|c|c|c|}
\hline \multirow[t]{2}{*}{ Variable } & \multicolumn{2}{|c|}{$2007^{\dagger}$} & \multicolumn{2}{|c|}{$2008^{\dagger}$} & \multicolumn{2}{|c|}{$2012^{\ddagger}$} & \multicolumn{2}{|c|}{$2013^{\ddagger}$} \\
\hline & Coefficient & $\begin{array}{l}p \text {-values for } \\
\text { two-tailed } \\
\text { significance }\end{array}$ & Coefficient & $\begin{array}{l}p \text {-values for } \\
\text { two-tailed } \\
\text { significance }\end{array}$ & Coefficient & $\begin{array}{l}p \text {-values for } \\
\text { two-tailed } \\
\text { significance }\end{array}$ & Coefficient & $\begin{array}{l}p \text {-values for } \\
\text { two-tailed } \\
\text { significance }\end{array}$ \\
\hline ROA & *1.574 & 0.051 & $* * 2.735$ & 0.038 & $* * * 4.013$ & 0.003 & $* * 2.600$ & 0.018 \\
\hline LOSS & 0.348 & 0.580 & -0.329 & 0.451 & 0.048 & 0.942 & -0.122 & 0.461 \\
\hline RE & -0.190 & 0.675 & -0.016 & 0.979 & -0.448 & 0.543 & 0.350 & 0.128 \\
\hline $\mathrm{CF}$ & -0.066 & 0.800 & 0.384 & 0.375 & 0.121 & 0.564 & 0.083 & 0.604 \\
\hline CASH & -0.013 & 0.314 & 0.022 & 0.205 & $* * 0.052$ & 0.018 & $* * 0.018$ & 0.014 \\
\hline $\mathrm{DE}$ & -0.083 & 0.198 & -0.042 & 0.677 & 0.049 & 0.490 & -0.053 & 0.341 \\
\hline GTH & **1.112 & 0.016 & 0.090 & 0.682 & 0.858 & 0.163 & -0.229 & 0.525 \\
\hline PD & -0.038 & 0.710 & 0.098 & 0.370 & -0.100 & 0.276 & $* * * 0.203$ & 0.001 \\
\hline RESTR & $*^{*} *_{-0} 0.626$ & 0.020 & 0.182 & 0.518 & -0.326 & 0.104 & -0.085 & 0.488 \\
\hline SIZE & 0.204 & 0.451 & 0.390 & 0.210 & 0.416 & 0.138 & 0.222 & 0.178 \\
\hline EMP & -0.831 & 0.355 & -0.402 & 0.700 & -0.304 & 0.450 & -0.166 & 0.592 \\
\hline CORP & -0.262 & 0.476 & $*-0.668$ & 0.099 & $* *-0.626$ & 0.040 & $* * 0.449$ & 0.040 \\
\hline $\mathrm{N}$ & 121 & - & 121 & - & 145 & - & 145 & - \\
\hline$R^{2}$ & $14.3 \%$ & - & $20.1 \%$ & - & $25.6 \%$ & - & $32.8 \%$ & - \\
\hline Chow-test & - & - & $* * * 14.590$ & $<0.001$ & - & - & $* * * 2.450$ & 0.004 \\
\hline
\end{tabular}

DPS, change in total dividend per share declared, excluding special dividends; ROA, change in return on total assets for the period, calculated as the change in earnings before interest and tax divided by average total assets in the current and prior period; LOSS, indicator variable set to one if a firm reports a basic loss per share and zero otherwise; RE, change in retained earnings as a percentage of common equity; $\mathrm{CF}$, indicator variable set to one if a firm reports negative cash generated by operations and zero otherwise; CASH, change in cash and cash equivalents per share; $\mathrm{DE}$, change in leverage, calculated as the book value of total assets to the book value of common equity in each period; GTH, change in 3-year annual compound growth rate in sales between the current and prior periods; PD, change in prior year dividend per share; RESTR, indicator variable set to one if the firm has discontinued operations in the current year and zero otherwise; SIZE, change in size, calculated as the natural log of the market value of the firm in each period; EMP, the percentage of outstanding common shares held by employees; CORP, the percentage of outstanding common shares held by corporate investors.

$\dagger, N=121 ; \neq, N=145$.

*Significant at the $10 \%$ level; **significant at the $5 \%$ level; ***significant at the $1 \%$ level.

Note: The Chow-test (Chow 1960) tests whether the coefficients of the first year are equal to those of the second year; DPS ${ }_{i, t}=\operatorname{ROA}_{i, t}+\operatorname{LOSS}_{i, t}+\mathrm{RE}_{i, t}+\mathrm{CASH}_{\mathrm{i}, \mathrm{t}}+\mathrm{CF}_{\mathrm{i}, \mathrm{t}}+\mathrm{DE}_{\mathrm{i}, \mathrm{t}}+\mathrm{GTH}_{\mathrm{i}, \mathrm{t}}+\mathrm{PD}_{\mathrm{i}, \mathrm{t}}+\mathrm{RESTR}_{\mathrm{i}, \mathrm{t}}+$ $\mathrm{SIZE}_{i, t}+\mathrm{EMP}_{\mathrm{i}, \mathrm{t}}+\operatorname{CORP}_{\mathrm{i}, \mathrm{t}}+\varepsilon$ 
Overall, the main regression results, therefore, imply that firms consider the tax preferences of their investors in determining dividend policies. In addition, corporate investors appear to have greater influence over their investees than individual investors when tax preferences conflict. This could be because of the size of their holdings or merely reflect that corporate investors tend to be better at organised lobbying than individuals.

\section{Additional analyses and robustness tests \\ Determining independent results for each year}

The main regression results reveal that growth in dividends is affected by the degree of corporate shareholding. However, it is possible that corporate shareholding affects the dividend itself (i.e. the level thereof) independently of changes in tax preferences. For this reason, the regression is also run using a levels specification. The results from this model specification are presented in Table 5 .

Table 5 reveals that corporate shareholding (CORP) is insignificant in all of the sample years, with the exception of 2013 (the year subsequent to the tax change). In this year, higher corporate shareholding is associated with significantly higher dividends per share at the $1 \%$ level $(p=0.009)$. These findings, therefore, imply that corporate shareholding does not affect the dividend levels independently of changes in tax preferences.

In addition, results from a Chow-test (Chow 1960) show that the determinants of dividends per share for the control sample of 2007-2008 are statistically indistinguishable between years $(p=0.704)$. By contrast, the determinants of dividends per share changed significantly after the 2012 tax change $(p<0.001)$. In other words, higher corporate shareholding played a unique role in setting dividend payouts subsequent to the 2012 tax change, which it did not do previously.

Results from this robustness test, therefore, imply that corporate shareholding does not affect dividends independently of changes in tax preferences. In addition, the findings also confirm that corporates successfully lobbied for higher dividends subsequent to the 2012 tax change, despite their new tax preferences conflicting with those of individuals.

\section{Controlling for cross-sectional correlation}

The main regression results do not control for cross-sectional correlation between firms, mainly because the tax change is itself severely cross-sectionally correlated in nature. In other words, decisions based on the tax change cannot be independent between firms. However, to investigate the impact of cross-sectional correlation, the regression is also run with robust standard errors clustered by firm. These results are presented in Table 6 .

Findings show that higher corporate shareholding continues to be associated with higher dividend growth subsequent to the 2012 tax change, albeit at the 10\% level ( $p=0.066)$. In addition, results continue to suggest that corporate investors successfully lobbied for slower dividend growth in anticipation of the tax changes, with CORP negative and significant at the $5 \%$ level ( $p=0.033$ ) during 2012. However, in the control sample of 2007 to 2008 , CORP is now insignificantly associated with growth in dividends in both

TABLE 5: Regression results determined independently per year

\begin{tabular}{|c|c|c|c|c|c|c|c|c|}
\hline \multirow[t]{2}{*}{ Variable } & \multicolumn{2}{|c|}{$2007^{\dagger}$} & \multicolumn{2}{|c|}{$2008^{\dagger}$} & \multicolumn{2}{|c|}{$2012^{\ddagger}$} & \multicolumn{2}{|c|}{$2013^{\ddagger}$} \\
\hline & Coefficient & $\begin{array}{l}p \text {-values for } \\
\text { two-tailed } \\
\text { significance }\end{array}$ & Coefficient & $\begin{array}{l}p \text {-values for } \\
\text { two-tailed } \\
\text { significance }\end{array}$ & Coefficient & $\begin{array}{l}p \text {-values for } \\
\text { two-tailed } \\
\text { significance }\end{array}$ & Coefficient & $\begin{array}{l}p \text {-values for } \\
\text { two-tailed } \\
\text { significance }\end{array}$ \\
\hline LOSS & 0.548 & 0.477 & -0.325 & 0.489 & -0.366 & 0.554 & 0.766 & 0.189 \\
\hline RE & 0.127 & 0.691 & 0.188 & 0.485 & 0.032 & 0.869 & -0.526 & 0.260 \\
\hline $\mathrm{CF}$ & 0.148 & 0.643 & 0.110 & 0.807 & 0.215 & 0.337 & 0.318 & 0.588 \\
\hline $\mathrm{DE}$ & -0.266 & 0.285 & -0.008 & 0.745 & $* * 0.037$ & 0.049 & $* 0.098$ & 0.093 \\
\hline GTH & 0.145 & 0.565 & **1.979 & 0.046 & 0.380 & 0.620 & 0.105 & 0.944 \\
\hline PD & $* * * 0.928$ & $<0.001$ & $* * * 1.043$ & $<0.001$ & $* * * 0.993$ & $<0.001$ & $* * * 1.515$ & $<0.001$ \\
\hline RESTR & $*_{-0.576}$ & 0.067 & 0.106 & 0.732 & -0.208 & 0.320 & 0.113 & 0.800 \\
\hline SIZE & $* * 0.124$ & 0.024 & 0.060 & 0.256 & 0.059 & 0.182 & -0.108 & 0.332 \\
\hline EMP & 0.215 & 0.850 & 0.316 & 0.778 & 0.050 & 0.911 & 0.493 & 0.690 \\
\hline CORP & -0.038 & 0.931 & -0.073 & 0.858 & 0.028 & 0.929 & $* * * 2.064$ & 0.009 \\
\hline Chow-test & - & - & 0.758 & 0.704 & - & - & $* * * 3.592$ & $<0.001$ \\
\hline
\end{tabular}

DPS, change in total dividend per share declared, excluding special dividends; ROA, change in return on total assets for the period, calculated as the change in earnings before interest and tax divided by average total assets in the current and prior period; LOSS, indicator variable set to one if a firm reports a basic loss per share and zero otherwise; RE, change in retained earnings as a percentage of common equity; CF, indicator variable set to one if a firm reports negative cash generated by operations and zero otherwise; CASH, change in cash and cash equivalents per share; percentage of common equity; $C F$, indicator variable set to one if a firm reports negative cash generated by operations and zero otherwise; CASH, change in cash and cash equivalents per share; $\mathrm{DE}$, change in leverage, calculated as the book value of total assets to the book value of common equity in each period; GTH, change in 3-year annual compound growth rate in sales between the
current and prior periods; PD, change in prior year dividend per share; RESTR, indicator variable set to one if the firm has discontinued operations in the current year and zero otherwise; SIZE, current and prior periods; PD, change in prior year dividend per share; RESTR, indicator variable set to one if the firm has discontinued operations in the current year and zero otherwise; SIZE,
change in size, calculated as the natural log of the market value of the firm in each period; EMP, the percentage of outstanding common shares held by employees; CORP, the percentage of change in size, calculated as the natural log of the market
outstanding common shares held by corporate investors.

$\uparrow, N=121 ; \uparrow, N=145$

*Significant at the $10 \%$ level; **significant at the $5 \%$ level; ***significant at the $1 \%$ level.

Note: The Chow-test (Chow 1960) tests whether the coefficients of the first year are equal to those of the second year; DPS ${ }_{i, t}=\operatorname{ROA}_{i, t}+\operatorname{LOSS}_{i, t}+\mathrm{RE}_{i, t}+\mathrm{CASH}_{i, t}+\mathrm{CF}_{i, t}+\mathrm{DE}_{\mathrm{i}, \mathrm{t}}+\mathrm{GTH}_{\mathrm{i}, \mathrm{t}}+\mathrm{PD}_{\mathrm{i}, \mathrm{t}}+\mathrm{RESTR}_{\mathrm{i}, \mathrm{t}}+$ $\mathrm{SIZE}_{\mathrm{i}, \mathrm{t}}+\mathrm{EMP}_{\mathrm{i}, \mathrm{t}}+\mathrm{CORP}_{\mathrm{i}, \mathrm{t}}+\varepsilon$. 
TABLE 6: Controlling for cross-sectional correlation.

\begin{tabular}{|c|c|c|c|c|c|c|c|c|}
\hline \multirow[t]{2}{*}{ Variable } & \multicolumn{2}{|c|}{$2007^{\dagger}$} & \multicolumn{2}{|c|}{$2008^{\dagger}$} & \multicolumn{2}{|c|}{$2012^{\ddagger}$} & \multicolumn{2}{|c|}{$2013^{\ddagger}$} \\
\hline & Coefficient & $\begin{array}{l}p \text {-values for } \\
\text { two-tailed } \\
\text { significance }\end{array}$ & Coefficient & $\begin{array}{l}p \text {-values for } \\
\text { two-tailed } \\
\text { significance }\end{array}$ & Coefficient & $\begin{array}{l}p \text {-values for } \\
\text { two-tailed } \\
\text { significance }\end{array}$ & Coefficient & $\begin{array}{l}p \text {-values for } \\
\text { two-tailed } \\
\text { significance }\end{array}$ \\
\hline ROA & 1.574 & 0.150 & $* 2.735$ & 0.084 & $* * 4.013$ & 0.023 & $* * 2.600$ & 0.046 \\
\hline LOSS & 0.348 & 0.862 & -0.329 & 0.327 & 0.048 & 0.931 & -0.122 & 0.367 \\
\hline RE & -0.190 & 0.682 & -0.016 & 0.972 & -0.448 & 0.476 & $* * 0.350$ & 0.050 \\
\hline $\mathrm{CF}$ & -0.066 & 0.690 & 0.384 & 0.112 & 0.121 & 0.446 & 0.083 & 0.538 \\
\hline $\mathrm{DE}$ & 0.083 & 0.327 & -0.042 & 0.523 & 0.049 & 0.253 & -0.054 & 0.316 \\
\hline GTH & *1.112 & 0.069 & 0.090 & 0.498 & $* 0.858$ & 0.089 & -0.229 & 0.396 \\
\hline PD & 0.038 & 0.841 & 0.098 & 0.658 & -0.100 & 0.564 & 0.203 & 0.102 \\
\hline RESTR & $*-0.626$ & 0.064 & 0.182 & 0.316 & $*_{-0.326}$ & 0.069 & -0.085 & 0.417 \\
\hline SIZE & 0.204 & 0.399 & 0.390 & 0.328 & $* 0.416$ & 0.093 & 0.222 & 0.159 \\
\hline EMP & *-0.831 & 0.072 & -0.402 & 0.555 & -0.305 & 0.252 & -0.166 & 0.365 \\
\hline CORP & -0.262 & 0.478 & -0.668 & 0.244 & $* *-0.626$ & 0.033 & $* 0.449$ & 0.066 \\
\hline Chow-test & - & - & $* * * 14.590$ & $<0.001$ & - & - & $* * * 2.450$ & 0.004 \\
\hline
\end{tabular}

DPS, change in total dividend per share declared, excluding special dividends; ROA, change in return on total assets for the period, calculated as the change in earnings before interest and tax divided by average total assets in the current and prior period; LOSS, indicator variable set to one if a firm reports a basic loss per share and zero otherwise; RE, change in retained earnings as a percentage of common equity; $\mathrm{CF}$, indicator variable set to one if a firm reports negative cash generated by operations and zero otherwise; $\mathrm{CASH}$, change in cash and cash equivalents per share; $\mathrm{DE}$, change in leverage, calculated as the book value of total assets to the book value of common equity in each period; GTH, change in 3-year annual compound growth rate in sales between the current and prior period; PD, change in prior year dividend per share; RESTR, indicator variable set to one if the firm has discontinued operations in the current year and zero otherwise; SIZE, change in size, calculated as the natural log of the market value of the firm in each period; EMP, the percentage of outstanding common shares held by employees; CORP, the percentage of outstanding common shares held by corporate investors.

$\dagger, N=121 ; \ddagger, N=145$

*Significant at the $10 \%$ level; **significant at the $5 \%$ level; $* * *$ significant at the $1 \%$ level.

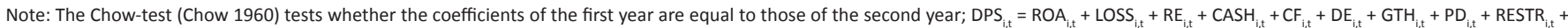
$\mathrm{SIZE}_{i, \mathrm{t}}+\mathrm{EMP}_{\mathrm{i}, \mathrm{t}}+\mathrm{CORP}_{i, \mathrm{t}}+\varepsilon$

sample years. Therefore, the main findings in respect of the 2007 tax change are not robust to controlling for crosssectional correlation.

In summary, controlling for cross-sectional correlation does not alter the main conclusions of this study. Results continue to imply that firms consider the tax preferences of their investors in determining dividend policies and that corporate investors have greater influence over their investees than individual investors when tax preferences conflict. However, it appears that lobbying in anticipation of future tax changes could be weaker than what the main results suggest.

\section{Ethical consideration}

This study was approved by the Research Ethics Committee of the University of Pretoria. It uses only secondary data that are publicly available.

\section{Summary and conclusion}

When investors with differing tax preferences invest in the equity of the same firm, this can lead to conflicting pressures on management to either retain earnings or distribute profits to investors. This article investigates the response of firms when their investors have conflicting tax preferences using a change in South African dividend tax on 01 April 2012 as its setting. Importantly, this tax change allows for unique investigations as it altered the tax preferences of two groups of investors, namely, individuals and corporates, simultaneously. Using a multivariate regression approach, this study considers the impact of corporate shareholding on growth in dividends prior and subsequent to the tax change during 2012 for a sample of South African firms.
This approach effectively tests the significance of changes in dividend growth (related to a difference in difference approach). In addition, the findings are cross-checked against an earlier tax change during 2007 (the control sample).

Findings show a significantly positive (negative) association between corporate shareholding and growth in dividends after (before) the 2012 tax change. In other words, after (before) this tax change, firms with higher corporate shareholding grew their dividends significantly faster (slower) than other firms. These findings imply that corporate shareholders had sufficient influence to align dividend policies of their investees with their tax preferences. This could be because of the size of their holdings or merely reflect that corporate investors tend to be better at organised lobbying than individuals. By contrast, findings from the control sample show that corporate shareholding had a limited impact on growth in dividends as a result of the 2007 tax change. In summary, this study, therefore, concludes that tax preferences of investors affect dividends. In addition, when tax preferences conflict, corporates appear to have greater influence over their investees than individuals.

This study contributes to the existing literature by revealing that investors place pressure on firms to minimise their own tax burden and that firms respond to this pressure through their dividend policies. In addition, it shows that, in the face of conflicting tax preferences, corporates appear to have greater influence than individuals.

The findings of this study will be of interest to researchers of taxation and corporate governance alike, as they highlight the role that corporate shareholders play in the decisions of the firm. Investors and regulators will also be interested in 
the findings, as they reveal more about the interaction between shareholders with conflicting interests. Lastly, changes in behaviour as a result of changes in tax legislation are of interest to those with fiscal responsibility.

However, the findings of this study are limited to tax changes that altered the tax preferences of corporate and individual investors simultaneously. In addition, the findings cannot be extrapolated to conflicting tax preferences between other groups of investors. Such questions are left to future research.

\section{Acknowledgements}

The author would like to thank Marna de Klerk, Petri Ferreira and Lizette Kotze for their helpful comments and suggestions.

\section{Competing interests}

The author declares that he has no financial or personal relationships that may have inappropriately influenced him in writing this article.

\section{References}

Al-Ajmi, J. \& Hussain, H.A., 2011, 'Corporate dividend decisions: Evidence from Saudi Arabia', Journal of Risk Finance 12(1), 41-56. https://doi.org/10.1108/ 15265941111100067

Alstadsæter, A. \& Fjærli, E., 2009, 'Neutral taxation of shareholder income? Corporate responses to an announced dividend tax', International Tax and Public Finance responses to an announced dividend tax', International Tax
16(4), 571-604. https://doi.org/10.1007/s10797-009-9107-2

Amromin, G., Harrison, P. \& Sharpe, S., 2008, 'How did the 2003 dividend tax cut affect stock prices?', Financial Management 37(4), 625-646. https://doi.org/10.1111/ j.1755-053X.2008.00028.x

Ayers, B.C., Cloyd, C.B. \& Robinson, J.R., 2002, 'The effect of shareholder-level dividend taxes on stock prices: Evidence from the Revenue Reconciliation Act of 1993', Accounting Review 77(4), 933-947. https://doi.org/10.2308/accr.2002. 77.4.933

Blouin, J.L., Raedy, J.S. \& Shackelford, D.A., 2011, 'Dividends, share repurchases, and tax clienteles: Evidence from the 2003 reductions in shareholder taxes', Accounting Review 86(3), 887-914. https://doi.org/10.2308/accr.00000038
Bond, S.R., Devereux, M.P. \& Klemm, A., 2005, Dissecting dividend decisions: Some clues about the effects of dividend taxation from recent UK reforms, IFS Working Papers, Institute for Fiscal Studies (IFS), No. 05/17, viewed n.d., from http://www. ifs.org.uk/wps/wp0517.pdf

Brockman, P. \& Unlu, E., 2011, 'Earned/contributed capital, dividend policy and disclosure quality: An international study', Journal of Banking \& Finance 35, 16101625. https://doi.org/10.1016/j.jbankfin.2010.11.014

Brown, J.R., Liang, N. \& Weisbenner, S., 2007, 'Executive financial incentives and payout policy: Firm responses to the 2003 dividend tax cut', Journal of Finance 62(4), 1935-1965. https://doi.org/10.1111/j.1540-6261.2007.01261.x

Chetty, R. \& Saez, E., 2005, 'Dividend taxes and corporate behavior: Evidence from the 2003 dividend tax cut', Quarterly Journal of Economics 120(3), 791-833. https:// doi.org/10.1093/qje/120.3.791

Chow, G.C., 1960, 'Tests of equality between sets of coefficients in two linear regressions', Econometrica 28, 591-605. https://doi.org/10.2307/1910133

Coetzee, S. \& De Wet, J., 2014, 'Dividend tax, dividend payments and share values: A South African perspective', Corporate Ownership and Control 11(3), 242-252. https://doi.org/10.22495/cocv11i3c2p3

Deangelo, H., Deangelo, L. \& Stulz, R.M., 2006, 'Dividend policy and the earned/ contributed capital mix: A test of the life-cycle theory', Journal of Financial Economics 81, 227-254. https://doi.org/10.1016/j.jfineco.2005.07.005

Edgerton, J., 2013, 'Four facts about dividend payouts and the 2003 tax cut', International Tax and Public Finance 20(5), 769-784. https://doi.org/10.1007/ s10797-012-9242-z

Goncharov, I. \& Van Triest, S., 2011, 'Do fair value adjustments influence dividend policy?', Accounting and Business Research 41(1), 51-68. https://doi.org/10.1080/ 00014788.2011.549637

IImanen, A., 2011, Expected returns: An investor's guide to harvesting market rewards, Wiley, Chichester.

Kari, S., Karikallio, H. \& Pirttilä, J., 2008, 'Anticipating tax changes: Evidence from the Finnish corporate income tax reform of $2005^{\prime}$ ' Fiscal Studies 29(2), 167-196. https://doi.org/10.1111/j.1475-5890.2008.00072.x

Minnick, K. \& Rosenthal, L., 2014, 'Stealth compensation: Do CEOs increase their pay by influencing dividend policy?', Journal of Corporate Finance 25, 435-454. https://doi.org/10.1016/j.jcorpfin.2014.01.005

Moser, W.J., 2007, 'The effect of shareholder taxes on corporate payout choice', Journal of Financial and Quantitative Analysis 42(4), 991-1020. https://doi. org/10.1017/S0022109000003471

Short, H., Zhang, H. \& Keasey, K., 2002, 'The link between dividend policy and institutional ownership', Journal of Corporate Finance 8, 105-122. https://doi. org/10.1016/S0929-1199(01)00030-X

Shrieves, R.E. \& Wachowicz, J.M., 2001, 'Free Cash Flow (FCF), Economic Value Added (EVA) and Net Present Value (NPV): A reconciliation of variations of DiscountedCash-Flow (DCF) valuation', Engineering Economist 46(1), 33-52. https://doi. org/10.1080/00137910108967561

Toerien, F. \& Marcus, M., 2014, 'The effect of South African dividend and capital gains taxes on share prices and investor expected returns', Journal of Applied Business Research 30(3), 895-908. https://doi.org/10.19030/jabr.v30i3.8574 